\title{
Penentuan Preferensi Masyarakat dalam Berdonasi Smartphone Bekas pada Lembaga Penyalur Donasi
}

\author{
Jessie Lestari ${ }^{1 *}$, Siana Halim², Debora Anne Yang Aysia ${ }^{3}$, Gan Shu San ${ }^{4}$ \\ ${ }^{1,2,3}$ Program Studi Teknik Industri, Universitas Kristen Petra, Surabaya, Indonesia \\ ${ }^{4}$ Program Studi Teknik Mesin, Universitas Kristen Petra, Surabaya, Indonesia \\ (*13180045@john.petra.ac.id)
}

\begin{abstract}
Abstrak - Pandemi COVID-19 yang tengah merebak telah menciptakan keadaan darurat bagi kesehatan seluruh masyarak Pandemi COVID-19 yang tengah merebak telah menciptakan keadaan darurat bagi kesehatan seluruh masyarakat di Indonesia. Salah satu upaya yang dilakukan oleh pemerintah dalam meminimalisir penyebaran virus adalah dengan membuat kebijakan untuk mengubah pembelajaran dari konvensional (di sekolah) menjadi pembelajaran daring dengan bantuan internet di rumah masing-masing (School From Home). Banyak siswa dari keluarga kurang mampu akhirnya terpaksa mengalami kesulitan dalam mengikuti kelas pembelajaran online karena siswa tidak memiliki perangkat yang memadai untuk mengikuti kegiatan pembelajaran online. Penelitian ini bertujuan untuk mengetahui preferensi donator dalam mendonasikan smartphone bekas berdasarkan faktor kepercayaan, keamanan, kenyamanan, dan kualitas pelayanan. Sebanyak 216 data dikumpulkan melalui kuesioner dengan teknik Incidental Sampling, dan data diolah dengan statistik deskriptif dan tabulasi silang di IBM SPSS Statistics versi 26. Hasil penelitian menunjukkan bahwa sebanyak 170 responden bersedia mendonasikan smartphone bekasnya, sebanyak $\mathbf{7 8 \%}$ di antaranya bersedia berdonasi, meskipun belum memiliki pengalaman dalam mendonasikan smartphone bekasnya dan hanya $8 \%$ dari responden yang memilih untuk tidak mendonasikan smartphone bekas mereka kembali.
\end{abstract}

Kata kunci: COVID-19; donasi; preferensi; smartphone bekas

\section{PENDAHULUAN}

Coronavirus Disease-19 adalah penyakit yang ditemukan di Wuhan, Cina, pada Desember 2019. COVID19 adalah penyakit yang disebabkan oleh virus korona jenis baru, Sars-CoV-2. Penyebaran virus ini terjadi dengan cepat dan mengganggu semua aktivitas masyarakat, mulai dari kegiatan bisnis hingga pendidikan. Pada 11 Maret 2020, World Health Organization menyatakan penyebaran COVID-19 sebagai pandemi setelah melihat jumlah virus yang menyebar dengan cepat ke seluruh dunia (World Health Organization, 2020). Melihat realitas permasalahan tersebut, pemerintah Indonesia sebagai salah satu negara yang terdampak memutuskan untuk menerapkan berbagai kebijakan social distancing untuk menekan penyebaran COVID-19 (Ihsanuddin, 2020). Salah satu sistem yang diterapkan adalah kebijakan pembelajaran online bagi siswa yang dikenal dengan School from Home (SFH). Dalam sistem pembelajaran online, setiap siswa harus memiliki alat pendukung berupa perangkat yang dapat terhubung dengan internet, seperti smartphone, tablet, laptop, dan komputer (Direktorat Sekolah Dasar, 2020). Berdasarkan penelitian Pramana et al (2021), terlihat bahwa selama pembelajaran online di tengah pandemi COVID-19, platform pembelajaran yang paling sering digunakan adalah WhatsApp. Melalui aplikasi tersebut pengajar dapat melakukan diskusi dan membagikan materi pembelajaran seperti file power point, file microsoft word, video dan link sumber lainnya (Susilawati \& Supriyanto, 2021)

Penggunaan smartphone dalam mendukung program SFH memiliki dampak baik yaitu mempermudah dan mempercepat alur komunikasi serta menarik bagi siswa (Sulaiman, 2020). Namun di sisi lain dampak dari penggunaan smartphone adalah banyak siswa dari keluarga dengan tingkat ekonomi rendah yang tidak dapat mengikuti kegiatan belajar secara optimal. Keadaan ini dapat terjadi karena banyak siswa yang tidak memiliki fasilitas belajar berupa device yang memadai. Meski sudah ada dukungan dari pemerintah berupa paket internet bulanan, banyak siswa yang masih mengalami kendala karena tidak memiliki smartphone yang dapat digunakan sebagai media pembelajaran. Salah satu contoh siswa terdampak datang dari Panti Asuhan Pelita Harapan Bangsa yang terletak di Banda Lampung. Ketua organisasi dari Yayasan mengatakan bahwa smartphone yang digunakan untuk pembelajaran online harus digunakan secara bergantian karena keterbatasan perangkat (hanya dua smartphone). Sementara itu dalam Yayasan tersebut terdapat 24 anak asuh yang bersekolah di TK hingga SMP yang membutuhkan perangkat pembelajaran. Karena perbedaan kelas dan jenjang sekolah, anak asuh harus mau bergiliran dalam mengambil pelajaran (Jaya, 2020). 
Berdasarkan permasalahan limbah elektronik, diketahui bahwa smartphone merupakan alat elektronik terbanyak yang dibuang di Indonesia (Santoso et al, 2019), seharusnya hal tersebut tidak menjadi masalah jika semua limbah ini dikumpulkan dan didaur ulang dengan benar. Namun berdasarkan statistik hanya terdapat sekitar 17\% dari limbah elektronik di dunia yang telah didaur ulang dengan benar pada tahun 2019 (Forti et al, 2020). Situasi ini bahkan lebih buruk di negara-negara berkembang seperti Indonesia dimana regulasi mengenai limbah elektonik masih kurang diperhatikan oleh masyarakat. Beberapa opsi yang dapat dilakukan oleh masyarakat untuk mengurangi limbah elektronik dari smartphone adalah dengan menjual smartphone kembali, mendonasikan smartphone kepada pihak yang membutuhkan, atau mendaur ulang smartphone (Scientific American, 2010). Penelitian ini diperlukan untuk mengetahui preferensi masyarakat dalam mendonasikan smartphone bekas melalui lembaga penyalur donasi.

\section{STUDI LITERATUR}

Menurut Kamus Besar Bahasa Indonesia, donasi adalah sumbangan dari penderma yang diberikan kepada perkumpulan atau derma. Pada umumnya sumbangan tidak harus berupa uang melainkan berbagai hal lain seperti waktu, barang, dan tenaga yang diberikan secara sukarela tanpa mengharapkan timbal balik. Lembaga perantara adalah badan organisasi yang berfungsi sebagai penyalur yang memiliki izin untuk mengumpulkan dan menyalurkan spesifik produk ke masyarakat. Pada penelitian ini terdapat empat lembaga yang diteliti sebagai tempat penyalur smartphone bekas yaitu: lembaga sosial, lembaga pendidikan, lembaga keagamaan, dan lembaga donasi online.

Lembaga sosial dan lembaga pendidikan dipilih dalam penelitian ini dikarenakan berhubungan langsung dengan penerima donasi yaitu pelajar yang mungkin berasal dari keluarga yang kurang mampu dan sedang membutuhkan smartphone. Kemudian lembaga keagamaan dipilih karena agama berpengaruh besar dalam pertimbangan dan perilaku moral masyarakat Indonesia, di mana dalam penelitian oleh Nuari dan Hendratmi (2020), terlihat bahwa Religiusitas berpengaruh signifikan terhadap minat memberikan donasi pada Lembaga Amil Zakat Sahabat Mustahiq, sedangkan lembaga donasi online dipilih karena merupakan lembaga khusus yang terbentuk setelah mendapatkan izin pemerintah dalam mengumpulkan bantuan berupa barang atau dana donasi yang akan disalurkan kepada korban atau pihak yang membutuhkan.

Pengambilan keputusan konsumen sangat penting bagi pemasar (lembaga penyalur) karena tahap ini menentukan apakah donator ingin mendonasikan smartphone bekas mereka atau tidak (Tawas, 2013). Keputusan konsumen berkaitan erat dengan informasi yang dimiliki dan diterima oleh konsumen, dan berbagai faktor yang dipengaruhi oleh pengetahuan konsumen tentang produk yang akan digunakan. Keputusan konsumen dipengaruhi oleh faktor lingkungan eksternal seperti budaya, sosial, pribadi, dan psikologis. Persepsi merupakan salah satu faktor psikologis yang dapat menunjukkan bagaimana seseorang dipengaruhi oleh pengetahuan dan pengalaman dalam menginterpretasikan masukan informasi untuk menciptakan gambaran (Setiadi, 2015).

Preferensi konsumen merupakan preferensi terhadap suatu produk tertentu dan mempengaruhi keputusan konsumen dalam menggunakan produk yang ditawarkan. Preferensi konsumen sangat menentukan dalam pemasaran karena berkaitan erat dengan keberhasilan perusahaan dalam mencapai tujuannya yaitu keputusan untuk berdonasi berdasarkan preferensi konsumen (Kotler, 2000). Tujuan dari penelitian ini adalah untuk mengetahui preferensi masyarakat dalam berdonasi smartphone berdasarkan faktor kepercayaan, keamanan, kenyamanan, dan kualitas layanan.

\section{METODOLOGI}

Penelitian diawali dengan identifikasi masalah untuk menentukan tujuan penelitian dan dilanjutkan oleh studi literatur untuk mendapatkan teori pendukung sebagai acuan dalam melaksanakan rangkaian tahap penelitian. Selanjutnya dilakukan pembuatan kuesioner untuk mengetahui preferensi masyarakat dalam berdonasi smartphone bekas pada lembaga penyalur. Desain kuesioner terbagi atas dua bagian, yaitu terdiri dari karakteristik responden yang meliputi pertanyaan seputar jenis kelamin, domisili, tingkat pendidikan, pekerjaan, dan histori donasi smartphone. Bagian kedua kuesioner terdiri dari pertanyaan yang berhubungan dengan preferensi masyarakat dalam berdonasi. Bagian ini memuat pertanyaan seputar teknologi, kondisi kerusakan, jenis smartphone dan nilai smartphone yang rela didonasikan, selain itu terdapat pertanyaan 
mengenai faktor kepercayaan, keamanan, kemudahan, dan kualitas pelayanan. Pada bagian ini juga donator ditanyai mengenai media donasi dan fasilitas yang sebaiknya dimiliki oleh lembaga penyalur, dan di akhir terdapat pertanyaan mengenai urutan keempat lembaga penyalur berdasarkan seluruh faktor dan mengenai minat donator dalam berdonasi smartphone bekas pada lembaga penyalur.

Responden pada penelitian ini terdiri atas pekerja dan siswa di seluruh Indonesia yang terbagi dalam dua kategori yaitu responden yang berasal dari Pulau Jawa dan luar Pulau Jawa. Kuesioner dituangkan dalam bentuk google-form dan disebarkan secara daring melalui media sosial. Penelitian ini menggunakan teknik Incidental Sampling, di mana penentuan sampel dilakukan secara kebetulan; Artinya, siapa saja yang kebetulan bertemu dengan peneliti dapat dijadikan sampel jika orang tersebut memenuhi kriteria. Menurut Sugiyono (2015) sampel yang baik berjumlah antara 30-500 orang responden.

Penelitian ini akan menggunakan pendekatan deskriptif kuantitatif, yang melibatkan teknik pengumpulan, pengelolaan, penyederhanaan, dan analisis data untuk memberikan gambaran bagaimana suatu peristiwa pengamatan dengan angka. Populasi dalam penelitian ini adalah calon donator smartphone bekas di Indonesia, Data yang digunakan dalam penelitian ini bersifat primer di mana data dikumpulkan lewat survei kuesioner berbasis online yang disebarkan lewat google-form. Pada awal penelitian telah dilakukan pilot study terhadap sepuluh donator untuk menguji kejelasan kuesioner sebelum disebarkan ke seluruh area di Indonesia. Kuesioner mulai disebar dari tanggal 16 Agustus 2021 sampai dengan 20 September 2021, dan telah dikumpulkan lebih dari 200 data responden. Pengolahan data menggunakan statistik deskriptif dengan tabulasi silang dan menampilkan frekuensi atau persentase untuk setiap variabel yang dihitung menggunakan IBM SPSS Statistics versi 26 (IBM Corporation).

\section{HASIL DAN DISKUSI}

Statistik deskriptif mengenai demografi dan karakteristik responden ditunjukkan pada Tabel 1. Penelitian ini mengumpulkan 216 data di antaranya terdapat 108 responden laki-laki (50\%), dan sisanya adalah perempuan (50\%). Responden terbanyak memiliki usia di antara 21 dan 30 tahun (49,5\%), kemudian diikuti oleh responden dengan usia di bawah $(<) 21$ tahun $(31,9 \%)$, kemudian dengan usia di atas $(>) 40$ tahun $(13,9 \%)$, dan responden dengan usia di antara 31 dan 40 sebanyak 4,6\%. Tingkat pendidikan tertinggi yang dicapai oleh sebagian besar responden (52,8\%) adalah "SMA atau SMK", diikuti oleh S1 $(38,4 \%)$, pascasarjana/S2 dan S3 $(7,4 \%)$, dan diploma $(1,4 \%)$. Sebagian besar responden tinggal di Pulau Jawa $(81,94 \%)$, dan hanya $18,1 \%$ yang tinggal di luar Pulau Jawa.

Tabel 1

Karakteristik responden

\begin{tabular}{clccc}
\hline Variabel & Kategori & $\mathrm{N}=216$ & Persentase (\%) \\
\hline \multirow{2}{*}{ Jenis Kelamin } & Laki - laki & 108 & $50,0 \%$ \\
& Perempuan & 108 & $50,0 \%$ \\
\hline \multirow{3}{*}{ Usia (Tahun) } & 21 & 69 & $31,9 \%$ \\
& $21-30$ & 107 & $49,5 \%$ \\
& $31-40$ & 10 & $4,6 \%$ \\
& $>40$ & 30 & $13,9 \%$ \\
\hline \multirow{2}{*}{ Domisili } & Pulau Jawa & 177 & $81,9 \%$ \\
& Luar Pulau Jawa & 39 & $18,1 \%$ \\
\hline \multirow{2}{*}{ Tingkat } & SMA/SMK & Diploma & 114 & $52,8 \%$ \\
& S1 & 3 & $1,4 \%$ \\
& S2 dan S3 & 83 & $38,4 \%$ \\
\hline \multirow{2}{*}{ Pekerjaan } & Pelajar & 16 & $7,4 \%$ \\
& Pekerja & 138 & $63,9 \%$ \\
\hline \multirow{2}{*}{ Histori donasi } & Belum pernah berdonasi & 78 & $36,1 \%$ \\
& Pernah berdonasi & 203 & $94,0 \%$ \\
\hline
\end{tabular}


Tabel 2

Preferensi berdasarkan faktor kepercayaan, keamanan, kemudahan, dan kualitas pelayanan

\begin{tabular}{|c|c|c|c|}
\hline Variabel & Kategori & $\mathrm{N}=216$ & Persentase $(\%)$ \\
\hline \multirow{5}{*}{ Informasi } & Dokumentasi penerimaan donasi & 127 & $58,8 \%$ \\
\hline & Nama penerima donasi & 84 & $38,9 \%$ \\
\hline & Alamat penerima donasi & 67 & $31,0 \%$ \\
\hline & Nama lembaga penyalur donasi & 124 & $57,4 \%$ \\
\hline & Tidak mengetahui informasi penerima donasi & 50 & $23,1 \%$ \\
\hline \multirow{5}{*}{ Keamanan } & Kerahasiaan data donator & 131 & $60,6 \%$ \\
\hline & $\begin{array}{l}\text { Keterbukaan berupa laporan terkait proses atau program yang } \\
\text { dilaksanakan }\end{array}$ & 164 & $75,9 \%$ \\
\hline & Keterbukaan berupa laporan terkait uang yang digunakan & 114 & $52,8 \%$ \\
\hline & Keterbukaan dalam data penerima donasi & 1 & $0,5 \%$ \\
\hline & $\begin{array}{l}\text { Keterbukaan dalam dokumentasi proses penyerahan barang } \\
\text { donasi }\end{array}$ & 1 & $0,5 \%$ \\
\hline \multirow{6}{*}{$\begin{array}{c}\text { Kualitas } \\
\text { Pelayanan }\end{array}$} & Keramahan dalam proses pelayanan & 128 & $59,3 \%$ \\
\hline & Kejelasan dalam proses pelayanan & 180 & $83,3 \%$ \\
\hline & Kecepatan dalam proses pelayanan & 103 & $47,7 \%$ \\
\hline & Laporan penyaluran donasi jelas & & \\
\hline & Transparansi & 1 & $0,5 \%$ \\
\hline & Memiliki tim auditor/pengawas kegiatan & 1 & $0,5 \%$ \\
\hline \multirow{3}{*}{ Kemudahan } & Prosedur jelas dan mudah dimengerti & 194 & $89,8 \%$ \\
\hline & Proses donasi Smartphone bekas dapat dilakukan kapan saja & 108 & $50,0 \%$ \\
\hline & $\begin{array}{l}\text { Tidak dibutuhkan banyak usaha dalam proses donasi (Tahap } \\
\text { dalam berdonasi sedikit) }\end{array}$ & 108 & $50,0 \%$ \\
\hline
\end{tabular}

Tabel 3

Tabulasi silang kredibilitas dan kemudahan-kualitas pelayanan

\begin{tabular}{|c|c|c|c|c|c|c|c|c|c|}
\hline \multirow[t]{3}{*}{ Kredibilitas } & \multirow[t]{3}{*}{$\mathrm{N}$} & \multicolumn{8}{|c|}{ Mudah dan Memiliki Kualitas Pelayanan Baik } \\
\hline & & \multicolumn{2}{|c|}{ Lembaga Sosial } & \multicolumn{2}{|c|}{$\begin{array}{c}\text { Lembaga } \\
\text { Keagamaan }\end{array}$} & \multicolumn{2}{|c|}{$\begin{array}{l}\text { Lembaga } \\
\text { Pendidikan }\end{array}$} & \multicolumn{2}{|c|}{$\begin{array}{c}\text { Lembaga Donasi } \\
\text { Online }\end{array}$} \\
\hline & & Iya & Tidak & Iya & Tidak & Iya & Tidak & Iya & Tidak \\
\hline Lembaga Sosial & 125 & 125 & 0 & 63 & 62 & 65 & 60 & 46 & 79 \\
\hline Lembaga Keagamaan & 97 & 59 & 28 & 77 & 20 & 54 & 43 & 34 & 63 \\
\hline Lembaga Pendidikan & 120 & 65 & 55 & 60 & 60 & 96 & 24 & 47 & 73 \\
\hline Lembaga Donasi Online & 76 & 34 & 42 & 29 & 47 & 35 & 41 & 67 & 9 \\
\hline
\end{tabular}

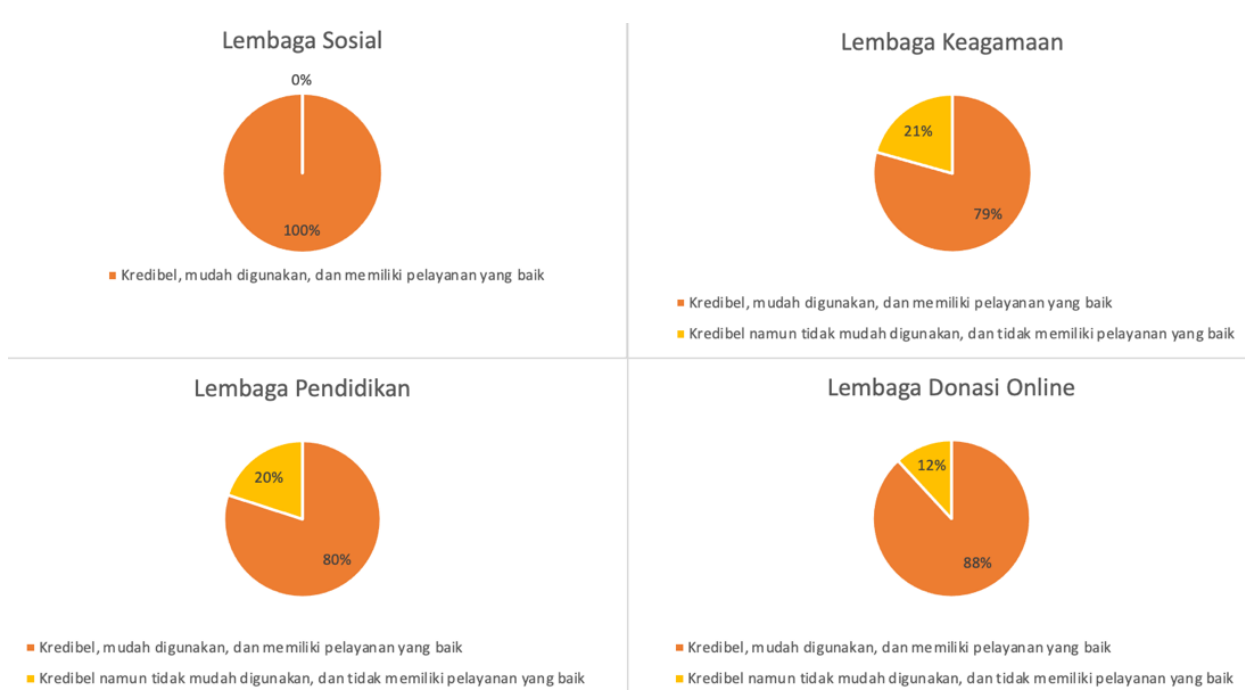

Gambar 2. Rangkuman tabulasi silang kredibilitas dan kemudahan-kualitas pelayanan 
Tabel 4

Preferensi responden berdasarkan tingkat kepentingan

\begin{tabular}{clcc}
\hline Variabel & \multicolumn{1}{c}{ Kategori } & N $=216$ & Persentase (\%) \\
\hline \multirow{2}{*}{ Media donasi } & Website & 64 & $29,6 \%$ \\
& Aplikasi & 39 & $18,1 \%$ \\
& Media Sosial & 118 & $54,6 \%$ \\
\hline \multirow{2}{*}{ Fasilitas lembaga } & Terdapat fasilitas Pick-up & 85 & $39,4 \%$ \\
penyalur & Terdapat lokasi drop barang di berbagai lokasi publik & 59 & $27,3 \%$ \\
& Terdapat banyak media untuk melakukan kegiatan donasi & 75 & $34,7 \%$ \\
\hline \multirow{2}{*}{ Nilai Smartphone } & $<$ Rp. 500.000 & 30 & $13,9 \%$ \\
bekas & <p. 900.000 1.400.000 & 52 & $24,1 \%$ \\
& $<$ Rp. 1.900.000 & 59 & $27,3 \%$ \\
& $>=$ Rp. 2.000.000 & 47 & $21,8 \%$ \\
Minat dalam & Iya & 28 & $13,0 \%$ \\
\hline berdonasi & Tidak & 170 & $78,7 \%$ \\
\hline
\end{tabular}

Berdasarkan Tabel. 1, sekitar 63,9\% responden adalah pelajar, dan 36,1\% responden adalah pekerja. Berdasarkan histori donasi, sebanyak $94 \%$ dari responden belum pernah mendonasikan smartphone bekasnya, dan hanya $6 \%$ responden yang pernah mendonasikan smartphone bekasnya. Berdasarkan faktor keamanan, sebagian besar responden menginginkan transparansi terkait program yang dilaksanakan, laporan keuangan, dokumentasi, dan nama penerima donasi. Sebagian besar responden ingin data mereka di rahasiakan atau tidak disebarluaskan (Tabel. 2). Berdasarkan Tabel 2, sebagian besar responden mengatakan bahwa kualitas lembaga donasi harus ramah, cepat, dan transparan dalam melayani, Lembaga sebaiknya memiliki pengawas, dan ada transparansi. Sebanyak $89,8 \%$ dari responden bersedia berdonasi jika laporan penyaluran donasi jelas dan mudah dipahami.

Berdasarkan Tabel 3 dan Gambar 1, sebanyak 125 responden memilih lembaga sosial sebagai lembaga yang dapat dipercayai dan kredibel. Semuanya mengatakan bahwa lembaga sosial memiliki kualitas pelayanan dan kenyamanan yang baik. Sebanyak 97 responden memilih lembaga keagamaan sebagai lembaga yang terpercaya dan kredibel, dan $79 \%$ di antaranya menyatakan bahwa lembaga keagamaan memiliki kualitas pelayanan dan kenyamanan yang baik. Terdapat 120 responden yang memilih lembaga pendidikan sebagai lembaga yang tepercaya dan kredibel, dan $80 \%$ diantaranya juga memilih lembaga pendidikan karena kualitas pelayanan dan kenyamanan yang baik. Sebanyak 76 memilih lembaga donasi online sebagai lembaga yang tepercaya dan kredibel, dan $88 \%$ dari mereka juga memilih lembaga donasi online untuk kualitas layanan dan kenyamanan yang baik.

Ditemukan bahwa sebanyak 114 responden memilih media sosial sebagai media yang paling mudah diakses untuk berdonasi smartphone bekas. Sebanyak 39,4\% dari responden ingin berdonasi jika lembaga penyalur memiliki fasilitas penjemputan. Sebagian besar responden bersedia berdonasi smartphone bekas dengan nilai di bawah $(<)$ Rp. 1.400 .000 (Tabel. 4). Sebanyak 170 responden bersedia berdonasi smartphone bekas mereka, $77,8 \%$ di antaranya ingin berdonasi meski belum pernah berdonasi smartphone bekas, dan terdapat sebanyak $92,3 \%$ dari responden yang pernah berdonasi smartphone bekas dan memiliki minat untuk berdonasi kembali.

\section{KESIMPULAN}

Pandemi COVID-19 telah menciptakan keadaan darurat kesehatan di Indonesia. Hal tersebut telah mengganggu kegiatan pendidikan karena adanya kebijakan untuk mengubah pembelajaran dari konvensional menjadi menggunakan program SFH dengan bantuan internet. Banyak siswa dari keluarga kurang mampu yang terpaksa mengalami kesulitan untuk mengikuti kelas pembelajaran online karena siswa tidak memiliki perangkat yang memadai. Penelitian ini bertujuan untuk mengetahui preferensi donator dalam mendonasikan smartphone bekas berdasarkan kepercayaan, keamanan, kenyamanan, dan kualitas layanan. Pengumpulan data dilakukan melalui kuesioner dan diolah dengan alat bantu SPSS. Hasil penelitian menunjukkan bahwa mayoritas responden membutuhkan lembaga penyalur yang dapat menjaga kerahasiaan data para donator. Mayoritas responden menginginkan lembaga penyalur memiliki transparansi mengenai program, laporan, dan 
dokumentasi dari penerima donor. Mayoritas responden $(89,9 \%)$ bersedia berdonasi bila terdapat kejelasan dan kemudahan dalam proses donasi.

Mayoritas responden memilih media sosial sebagai media yang mudah untuk memproses donasi, namun mayoritas responden $(39,4 \%)$ juga menginginkan lembaga penyalur untuk memiliki fasilitas penjemputan barang donasi. Fasilitas tersebut tidak dapat dilacak melalui media sosial, jadi disarankan untuk menggunakan media website atau aplikasi sebagai platform proses donasi, dan media sosial akan digunakan untuk berfokus dalam kampanye program donasi dan iklan. Hasil penelitian juga menunjukkan bahwa masih terdapat responden yang tidak memiliki minat dalam berdonasi smartphone bekas. Kampanye dapat menjadi solusi untuk menyadarkan masyarakat bahwa smartphone bekas milik mereka yang tidak digunakan lagi dapat didonasikan untuk membantu pelajar kurang mampu di tengah pandemi COVID-19, berdasarkan kegiatan kampanye tersebut penelitian selanjutnya dapat meneliti mengenai pengaruh kampanye terhadap minat masyarakat dalam berdonasi smartphone bekas.

Penelitian lanjutan lainnya yang bisa dilakukan berdasarkan penelitian ini adalah memperdalam preferensi masyarakat mengenai platform donasi yang dibutuhkan berdasarkan faktor kemudahan (sistem) dan kualitas pelayanan (fasilitas), sehingga dapat dibuatkan platform donasi yang berfokus untuk mengumpulkan smartphone bekas yang tidak dibutuhkan lagi oleh donator. Penelitian lanjutan yang dapat dilakukan adalah pembuatan model proses bisnis yang dapat berfokus dalam mengumpulkan, menginspeksi, memperbaiki, dan mendistribusikan smartphone bekas yang layak kepada pelajar yang membutuhkan.

\section{DAFTAR PUSTAKA}

Direktorat Sekolah Dasar. (2020, Oktober 21). Pembelajaran Jarak Jauh (PJJ) Bisa Jadi Model Pendidikan Masa Depan. Direktorat Sekolah Dasar. http://ditpsd.kemdikbud.go.id/artikel/detail/pembelajaran-jarakjauh-pjj-bisa-jadi-model-pendidikan-masa-depan.

Forti V., Baldé C.P., Kuehr R., Bel G. The Global E-waste Monitor 2020: Quantities, flows and the circular economy potential. United Nations University (UNU)/United Nations Institute for Training and Research (UNITAR) - co-hosted SCYCLE Programme, International Telecommunication Union (ITU) \& International Solid Waste Association (ISWA), Bonn/Geneva/Rotterdam.

Ihsanuddin. (2020, Maret 22). Jokowi: Physical Distancing Paling Pas untuk Cegah Covid-19 di Indonesia. Kompas. https://nasional.kompas.com/read/2020/03/24/12054741/jokowi-physical-distancing-palingpas-untuk-cegah-covid-19-di-indonesia?page=all.

Jaya, T. P. (2020, Oktober 14). Cerita 24 Anak Panti Asuhan Bergantian Belajar Online Pakai 2 Ponsel. Kompas. $\quad$ https://regional.kompas.com/read/2020/10/14/13072061/cerita-24-anak-panti-asuhanbergantian-belajar-online-pakai-2-ponsel?page=all.

KBBI. Donasi. KBBI Daring. https://kbbi.kemdikbud.go.id/entri/donasi

Kotler, P. (2000). Prinsip - Prinsip Pemasaran Manajemen. Jakarta: Prenhalindo.

Nuari, R., \& Hendratmi, A. (2020). FAKTOR MINAT BERDONASI PADA LEMBAGA AMIL ZAKAT SAHABAT MUSTAHIQ. Jurnal Ekonomi Syariah Teori Dan Terapan, 6(11), 2272. https://doi.org/10.20473/vol6iss201911pp2272-2282

Pramana, C., Susanti, R., Ernawati, K., Darmawan, I. P. A., Miftah, M. Z., Lestyowati, J., ... Ramadhani, R. (2021). Distance Learning In Primary Schools During The Covid-19 Pandemic In Indonesia: Challenges, Solutions, And Projections. Turkish Journal of Computer and Mathematics Education (TURCOMAT), 12(4), 263-270. https://doi.org/10.17762/turcomat.v12i4.502

Scientific American. (2010, April 28). One person's trash is another's technology: Recycling or donating discarded electronic equipment help reduce e-waste pollution. Scientific American. https://www.scientificamerican.com/article/earth-talk-recycling-e-equipment/.

Setiadi, N. J. (2015). Perilaku Konsumen: Edisi Revisi. Kencana.

Sulaiman, J. M. (2020). Pengaruh Media Belajar Smartphone Terhadap Belajar Siswa Di Era Pandemi Covid19: (The Influence of Smartphone Learning Media on Student Learning in The Era Pandemi Covid19). Indonesian Educational Administration and Leadership Journal, 2(2), 94-106. Retrieved from https://online-journal.unja.ac.id/IDEAL/article/view/10465

Susilawati, S., \& Supriyatno, T. (2020). Online Learning Through WhatsApp Group in Improving Learning Motivation in the Era and Post Pandemic COVID -19. Jurnal Pendidikan: Teori, Penelitian, dan Pengembangan, 5(6), 852 — 859. doi:http://dx.doi.org/10.17977/jptpp.v5i6.13670 
Tawas, S. (2013). Atribut Produk, Harga, Dan Strategi Promosi Pengaruhnya Terhadap Keputusan Pembelian Konsumen Pada Mobil Toyota Vios Di Pt. Hasjrat Abadi Manado. Jurnal Emba: Jurnal Riset Ekonomi, Manajemen, Bisnis Dan Akuntansi. 1(4). doi: https://doi.org/10.35794/emba.1.4.2013.2912

World Health Organization. (2020). Pertanyaan dan jawaban terkait Coronavirus. World Health Organization. https://www.who.int/indonesia/news/novel-coronavirus/qa/qa-for-public. 